\title{
Effects of incorporating oasis by-products on fattening performance and carcass characteristics of Ouled Djellal lamb
}

\author{
Abdelhamid Baa ${ }^{1,2}$, Fodil Arbouche ${ }^{3}$, Rafik Arbouche ${ }^{3}$, Etienne Montaigne ${ }^{4}$, Yasmine Arbouche ${ }^{5}$ and \\ Halima Saâdia Arbouche ${ }^{3}$
}

\begin{abstract}
1. Department of Agronomy, Faculty of Science of Nature and Life, University of El Tarf, El Tarf, Algeria; 2. Department of Agronomy, Faculty of Science of Nature and Life, University of M'sila, M'Sila, Algeria; 3. Department of Agronomy, Faculty of Science of Nature and Life, University of Ghardaia, Ghardaia, Algeria; 4. Joint Research Unit "Market, Organization, Institution", Actors Strategies, University Supagro of Montpellier, Montpellier, France; 5. Department of Agronomy, Faculty of Science of Nature and Life, University of Sétif, Sétif, Algeria.

Corresponding author: Fodil Arbouche, e-mail: arbouchefodil@yahoo.fr

Co-authors: AB: baahamid75@yahoo.fr, RA: rafik_arbouche@yahoo.fr, EM: etienne.montaigne@supagro.fr, YA: yas.arbouche@yahoo.fr, HSA: arbouchehs@yahoo.fr

Received: 02-06-2018, Accepted: 04-09-2018, Published online: 09-10-2018
\end{abstract}

doi: 10.14202/vetworld.2018.1397-1403 How to cite this article: Baa A, Arbouche F, Arbouche R, Montaigne E, Arbouche Y, Arbouche HS (2018) Effects of incorporating oasis by-products on fattening performance and carcass characteristics of Ouled Djellal lamb, Veterinary World, 11(10): 1397-1403.

\begin{abstract}
Aim: The aim of this study was to determine the effects of incorporating three local oasis by-products [cull dates (CDs), date pedicels (DPs) treated with urea, and juice from rumen content] into the food ration of Ouled Djellal lambs on fattening performance and carcass characteristics.

Materials and Methods: The experiment was carried out over 105 days, with an adaptation period of 15 days, on four groups each consisting of 10 male Ouled Djellal lambs aged 7-8 months with an average live body weight of $32 \pm 1.5 \mathrm{~kg}$, randomly distributed, and raised in tie stalls. The basic rations were formulated at a rate of $0 \%$ (control), 50\%, 80\%, and $100 \%$ substitution of barley straw by DPs treated with urea. The additional rations intended for the experimental groups consisted of $100 \%$ substitution of corn by CDs. Before distributed, they were sprayed with rumen content extract (RCE) at a rate of $250 \mathrm{ml} / \mathrm{kg}$.

Results: The $100 \%$ group displayed a highly significant difference compared to the other groups, with a live body weight of $43 \mathrm{~kg}(\mathrm{p}<0.05)$, an average daily gain of $191 \mathrm{~g}$, and feed efficiency of 5.08. These three parameters developed in proportion to the rates of incorporation of CDs and pedicels treated with urea. The carcass yield of the 100\% group (48.7\%) is significantly higher than the other groups while the thickness of back fat is significantly lower. Economically speaking, the profit margin of the $100 \%$ group is 30.93 Algerian dinars (DZD) per day per animal.

Conclusion: The use of by-products of the date palm (CDs and pedicels) combined with RCE in animal feed with a view to fattening sheep, in particular in oasis zones, represents an alternative in enhancing growth performances and carcass characteristics and offers a relatively cheap prospect for the availability of red meat for populations with low purchasing power.
\end{abstract}

Keywords: cull dates, date pedicels, extract of rumen content, sheep fattening.

\section{Introduction}

Reducing the cost price of $1 \mathrm{~kg}$ of ovine meet requires a reduction in the cost of feed, which accounts for $>47 \%$ of the overall production cost [1]. In light of the global economic crisis and the fall in oil prices, emerging countries such as Algeria, which imported all the raw materials used for livestock feed formulas, are forced to find solutions capable of reducing imports while maintaining the purchasing power of the poorest sections of the population. The use of non-conventional foods, such as agricultural and agro-industrial by-products, is a possible solution,

Copyright: Baa, et al. Open Access. This article is distributed under the terms of the Creative Commons Attribution 4.0 International License (http://creativecommons.org/licenses/by/4.0/), which permits unrestricted use, distribution, and reproduction in any medium, provided you give appropriate credit to the original author(s) and the source, provide a link to the Creative Commons license, and indicate if changes were made. The Creative Commons Public Domain Dedication waiver (http://creativecommons.org/ publicdomain/zero/1.0/) applies to the data made available in this article, unless otherwise stated. even if improving their nutritional qualities requires chemical treatment $[2,3]$. In oasis zones, the volume of products discarded by packing facilities and of cull from the date processing units (date paste) is quite considerable [4].

Algeria has large quantities of agro-industrial by-products which can be recycled as animal feed, in particular, the by-products of apricot processing in semiarid zones [5] and the by-products of date palms in oasis zones [6,7] comprising pedicels, palms, cull dates (CDs), and pits which can form the rations of small ruminants $[8,9]$.

In the abattoirs, the rumen content is tipped into landfill sites and represents a source of pollution estimated at an average of $25 \mathrm{~kg}$ per slaughtered animal [10]. Recycling this content could be feasible as its chemical composition totals, on average, $13.4 \mathrm{~kg}$ of dry matter (DM), $21.8 \%$ crude protein (of which $73.4 \%$ amino acids), $30.3 \%$ raw fiber, $6.1 \%$ fat, and $11.5 \%$ ash [11]. 
Rumen content has been used in animal feed $[12,13]$. Extracts of rumen content improve livestock farming performances [14].

The present study examined the possibility of incorporating three local oasis by-products: Date pedicels (DPs) treated with urea substituted for barley straw in the basic ration and CDs substituted for corn in the additional ration, with the latter soaked in the rumen content extract (RCE) when distributed.

\section{Materials and Methods \\ Ethical approval}

The present study was conducted after approval of the Institutional Animal Ethics Committee Laboratory of the Agriculture Department, Ghardaia University, Algeria.

\section{Diets, animals, and experimental protocol}

The three oasis by-products used in the experiment come from the region of Sidi Okba (Wilaya of Biskra). CDs of the "Deglet Nour" variety and DPs from a whole year were collected from the packing facilities in the region of Sidi Okba (Wilaya of Biskra in South-East Algeria). The CDs were crushed using a hammer mill fitted with a $1 \mathrm{~mm}$ grate. The chemical composition is presented in Table-1.

The DPs from 1 year were chopped and made into bundles of 10-15 kg to facilitate treatment with urea (Table-2) [9].

Containing $46.6 \%$ nitrogen, urea was used for the chemical treatment process. The solution contained $70 \mathrm{~g}$ urea/L of water for $1 \mathrm{~kg}$ DM [6]. The treatment lasted 35 days in a dark, anaerobic environment created using a black plastic film at a temperature of between $34^{\circ} \mathrm{C}$ and $37^{\circ} \mathrm{C}$.

Table-1: Chemical composition of CDs.

\begin{tabular}{lc}
\hline Mineral substances (\% of DM) & 2.9 \\
Total nitrogenous matter (\% of DM) & 4.2 \\
Crude fiber (\% of DM) & 9.4 \\
Fat (\% of DM) & 8.2 \\
Total sugars (\% of DM) & 63.87 \\
Gross energy (kcal/kg of DM) & 4.235 \\
Meat feed unit & 1.12 \\
\hline
\end{tabular}

$\mathrm{CDs}=$ cull dates $\mathrm{DM}=$ Dry matter
The rumen content was collected from the sheep abattoirs immediately after the animals were gutted. After being spread on the plastic film, the rumen content was treated with a $1 \%$ solution of hydrochloric acid to prevent flies from laying any eggs. It was dried in the fresh air after the rumen matter had been turned several times. The RCE was obtained by adding $1 \mathrm{~L}$ of water heated to $80^{\circ} \mathrm{C} / \mathrm{kg}$ of rumen content $(\mathrm{L} / \mathrm{kg})$ and kneading every $6 \mathrm{~h}$ for $24 \mathrm{~h}$. After filtering, the extract was placed in a fridge at a temperature of $6^{\circ} \mathrm{C}$. The nitrogenous chemical composition was determined according to the KJELDAHL method and the amino acids by high-performance liquid chromatography. The results are shown in Table-3.

The test was carried out on the pilot farm of Yahïa Ben Aïchouche (Algeria) where 40 Ouled Djellal lambs aged 7-8 months and weighing $32 \pm 1.5 \mathrm{~kg}$ were randomly divided into four groups of 10 according to diet and housed in tie stalls. All the animals were dewormed and identified by means of tags before the experiment was launched. The test lasted for 105 days, with a 15-day adaptation period.

The basic ration comprised barley straw, oat hay, and treated DPs (Table-4). In the experimental groups, the barley straw was substituted by treated pedicels at a rate of $50 \%$ (group 50), 80\% (group 80), and $100 \%$ (group 100). The basic ration was distributed as follows:

- Morning: Barley straw and treated DPs

- Evening: Oat hay.

Two types of additional ration were prepared (Table-5) [15], with the control group receiving a commercial ration made from corn $(60 \%)$ and the experimental groups receiving a ration, in which the corn was entirely replaced by CDs. The additional ration of the experimental groups was sprayed with $250 \mathrm{ml}$ of filtrate $/ \mathrm{kg}$ and distributed immediately to offset the deficit in nitrogenous matter in the CDs.

The animals were weighed individually every month at a specific time after $12 \mathrm{~h}$ without food using an electronic weight crate with a maximum weight of $100 \mathrm{~kg}$ and precise to $5 \mathrm{~g}$.

The basic ration was distributed ad libitum, limiting refusal to between $5 \%$ and $10 \%$. The concentrate

Table-2: Chemical composition of DPs[9].

\begin{tabular}{lccccc}
\hline Designation & DM \% & \multicolumn{3}{c}{ \% of DM } \\
\cline { 3 - 6 } & & OM & TNM & CF & MM \\
\hline Pedicels from 1 year treated under black plastic film & 86.28 & 94.88 & 13.62 & 32.18 & 5.12 \\
\hline
\end{tabular}

$\mathrm{DPs}=$ Date pedicels. $\mathrm{DM}=$ Dry matter, $\mathrm{OM}=$ Organic matter, $\mathrm{TNM}=$ Total nitrogenous matter, $\mathrm{CF}=\mathrm{Crude}$ fiber, $\mathrm{MM}=\mathrm{Ash}$

Table-3: Content of the ovine RCE in terms of nitrogenous matter ( $\%$ of DM) and amino acids (\% of TNM).

\begin{tabular}{lllllllll}
\hline RCE (\%) TNM & \multicolumn{6}{c}{ Amino acid content } \\
\cline { 2 - 9 } & \multicolumn{4}{c}{ Cystine } & Methionine & Threonine Lysine Glutamic acid Aspartic acid Arginine & Leucine Isoleucine \\
\cline { 2 - 10 }
\end{tabular}

$\mathrm{RCE}=$ Rumen content extract, $\mathrm{DM}=$ Dry matter, TNM=Total nitrogenous matter 
Table-4: Composition and nutrient content of the basic ration.

\begin{tabular}{lcccc}
\hline Ingredients $(\mathbf{g})$ & Control & Group 50 & Group 80 & Group 100 \\
\hline Barley straw & 700 & 350 & 140 & 0 \\
Treated pedicels & & 350 & 560 & 700 \\
Oat hay & 700 & 700 & & 700 \\
Nutrient content as \% & & & & 91.55 \\
$\quad$ Dry matter & 94.75 & 92.75 & 1.5 & 1.5 \\
Fat & 1.5 & 6.5 & 8.43 & 9.55 \\
Crude protein & 3.95 & 41.425 & 39.94 & 38.95 \\
Crude fiber & 43.9 & 5.45 & 5.45 & 5.45 \\
Mineral substances & 5.45 & 0.24 & 0.25 & 0.26 \\
MFU & 0.22 & & & \\
\hline
\end{tabular}

MFU=Meat feed unit

Table-5: Feed formulae of the additional rations (in $\% 100$ of feed).

\begin{tabular}{lcc}
\hline Ingredients & $\begin{array}{c}\text { Control } \\
\text { group }\end{array}$ & $\begin{array}{c}\text { Experimental } \\
\text { groups }\end{array}$ \\
\hline Corn & 60 & 0 \\
Cull dates & 0 & 60 \\
Soya meal & 20 & 20 \\
Wheat bran & 9 & 9 \\
Carob & 9 & 9 \\
Salt & 1 & 1 \\
CMV & 1 & 1 \\
Rumen fluid (ml/kg) & 0 & 250 \\
Nutrient content as \% & & \\
Dry matter & 85.31 & 87.71 \\
Fat & 2.59 & 2.61 \\
Crude protein & 16.23 & 16.25 \\
Crude fiber & 7.53 & 7.90 \\
Mineral substances & 6.83 & 6.34 \\
MFU* & 1.14 & 1.15 \\
\hline
\end{tabular}

*Calculated according to the equations proposed by Sauvant et al. [15], CMV=Complement mineral vitamin, $\mathrm{MFU}=$ Meat feed unit

was dispensed at a rate of $2 \mathrm{~kg} / 100 \mathrm{~kg}$ of live weight (LW) and readjusted by $5 \%$ at the end of the test by maintaining a refusal of $100 \mathrm{~g} / \mathrm{animal} / \mathrm{day}$. A mineral lick was made freely available to each group at watering.

At the end of the test, all the animals in each group were slaughtered after a period of $12 \mathrm{~h}$ without food. The carcasses were weighed hot ( $\mathrm{HC})$ and then placed in a cold room at $4^{\circ} \mathrm{C}$ to determine the cold carcass weight (CC). The thickness of back fat was also measured on the CC [16]. Echoing, Boccard and Dumont [17], other measurements were taken, indicating the width of the pelvis $(\mathrm{G})$, width of the thorax (LAC), width of the shoulders (M), depth of the breast $(\mathrm{TH})$, length of the carcass $(\mathrm{K})$, length of the leg $(\mathrm{F})$, and thickness of the leg. The density index for the leg (width/length) and carcass (width/length), the muscle index (thickness over length of leg), the carcass index (weight over length of carcass), and the conformation index $(\mathrm{g} / \mathrm{cm})$, which is the sum of the two previous indices, were also calculated.

\section{Statistical analysis}

The descriptive statistics and the variance analysis of the univariate general linear model (ANOVA) were implemented using the Statistical Package for the Social Sciences software (SPSS version 21, IBM, USA), to analyze the LW, the average daily gain (ADG), the average daily intake (ADI), and the feed conversion ratio (FCR). The general linear model was used to test the effects of the factors (substitutions) on the variables, while the post hoc test was used by applying the Student-Newman-Keuls and Duncan tests to estimate the significance or homogeneity between the different subgroups (comparison test between averages). The differences are deemed to be significant with an error risk of $5 \%$.

\section{Results}

Incorporating DPs in the basic ration to replace barley straw and the substitution of corn by CDs in the additional ration significantly influenced the final LW of the lambs in the experimental groups compared to the control group (Table-6). The ADG and ADI in the $0 \%, 50 \%$, and $80 \%$ groups remain unchanged while those of the $100 \%$ group are significantly different ( $+46 \%$ and $+7 \%$, respectively). The FCR of the $100 \%$ group $(5.08 \mathrm{~g}$ of $\mathrm{DM} / \mathrm{g})$ is significantly different from the other four groups.

The $50 \%$ group displays the smallest change in LW for the experiment as a whole (Figure-1). The $0 \%$ and $80 \%$ groups show a similar variation in LW until the $60^{\text {th }}$ day, with a difference at the $90^{\text {th }}$ day in favor of the $80 \%$ group. For the $100 \%$ group, the change in LW is significantly higher than the other groups.

The measurements of the carcass characteristics are presented in Table-7. There is no significant difference in the $\mathrm{HC}$ and $\mathrm{CC}$ weight between the different groups. Drying in the cold room generated a difference in carcass weight of about 0.6 points. The type of diet significantly $(p<0.05)$ influenced the carcass yield between the control group and the $100 \%$ group (44.66\% vs. $48.77 \%$, respectively). The yield of the $50 \%$ group was similar to that of the control group, whereas it was intermediate for the $80 \%$ group at $47.31 \%$.

A significant reduction $(\mathrm{p}=0.02)$ in back fat was recorded for the $50 \%$ and $100 \%$ groups compared to the control group. The $80 \%$ group displayed an intermediate thickness of back fat $(3.56 \%)$ and remained lower than that of the control group (3.93\%). 
Table-6: Fattening performances of Ouled Djellal lambs.

\begin{tabular}{lcccccc}
\hline Parameters & Lo & L50 & L80 & L100 & SEM & p-value \\
\hline Initial LW (kg) & 32.3 & 31.7 & 32.1 & 32.4 & 0.43 & 0.95 \\
Final LW (kg) & $39.6^{\mathrm{a}}$ & $40.1^{\mathrm{ab}}$ & $40.5^{\mathrm{ab}}$ & $43.1^{\mathrm{b}}$ & 0.55 & 0.01 \\
ADG (g) & $130.35^{\mathrm{a}}$ & $149.10^{\mathrm{a}}$ & $150^{\mathrm{a}}$ & $191.07^{\mathrm{b}}$ & 5.47 & 0.001 \\
ADI (g/animal/day) & $900.9^{\mathrm{a}}$ & $917.8^{\mathrm{a}}$ & $922.3^{\mathrm{a}}$ & $963.4^{\mathrm{b}}$ & 12.56 & 0.001 \\
FCR (g DM/g) & $7.34^{\mathrm{b}}$ & $6.49^{\mathrm{b}}$ & $6.27^{\mathrm{ab}}$ & $5.08^{\mathrm{a}}$ & 0.25 & 0.01 \\
\hline
\end{tabular}

In each line, the numbers followed by the same exponents do not differ significantly at $\mathrm{p}<0.05, \mathrm{SEM}=\mathrm{Standard}$ error of the mean, $L W=$ Live weight, $A D G=$ Average daily gain, $A D I=$ Average daily intake, $F C R=$ Feed conversion ratio, $D M=D r y$ matter

Table-7: Effects of incorporating DPs and cull dates on the characteristics of Ouled Djellal lamb carcasses.

\begin{tabular}{|c|c|c|c|c|c|c|}
\hline Parameters & $\mathbf{0}$ & 50 & 80 & 100 & SEM & p-value \\
\hline Hot carcass weight $(\mathrm{kg})$ & 20.13 & 20.26 & 20.46 & 22.93 & 0.57 & 0.28 \\
\hline Cold carcass weight $(\mathrm{kg})$ & 19.5 & 19.53 & 19.9 & 22.43 & 0.57 & 0.22 \\
\hline Carcass yield (\%) & $44.66^{\mathrm{a}}$ & $45.35^{\mathrm{a}}$ & $47.31^{\mathrm{ab}}$ & $48.77^{b}$ & 0.63 & 0.01 \\
\hline Thickness of back fat $(\mathrm{cm})$ & $3.93^{b}$ & $3.46^{\mathrm{a}}$ & $3.56^{\mathrm{ab}}$ & $3.23^{\mathrm{a}}$ & 0.09 & 0.02 \\
\hline Thickness of leg $(\mathrm{cm})$ & 30.66 & 27.13 & 30.23 & 30.9 & 0.9 & 0.47 \\
\hline Width of pelvis $(\mathrm{G})(\mathrm{cm})$ & 22.63 & 20.96 & 21.26 & 23.0 & 0.57 & 0.58 \\
\hline Width of chest (LAC) $(\mathrm{cm})$ & 19.16 & 19.83 & 19.30 & 20.56 & 0.62 & 0.89 \\
\hline Width of shoulders $(M)(\mathrm{cm})$ & 15.86 & 16.33 & 15.66 & 17.93 & 0.43 & 0.25 \\
\hline Length of carcass $(\mathrm{K})(\mathrm{cm})$ & 66.33 & 67.50 & $67.66^{a}$ & 68.00 & 0.95 & 0.95 \\
\hline Depth of chest $(\mathrm{TH})(\mathrm{cm})$ & 30.2 & 26.4 & 29.86 & 30.3 & 0.95 & 0.45 \\
\hline Length of leg $(F)(\mathrm{cm})$ & 33.96 & 37.00 & 35.00 & 36.83 & 0.69 & 0.37 \\
\hline Leg index (width/length) & $0.66^{\mathrm{b}}$ & $0.56^{a}$ & $0.60^{\mathrm{ab}}$ & $0.62^{\mathrm{ab}}$ & 0.015 & 0.03 \\
\hline Carcass index 1 (width/length) & 0.29 & 0.29 & 0.28 & 0.30 & 0.008 & 0.91 \\
\hline Muscle index (thickness/length of leg) & $0.90^{\mathrm{b}}$ & $0.73^{a}$ & $0.86^{\mathrm{ab}}$ & $0.84^{\mathrm{ab}}$ & 0.026 & 0.01 \\
\hline Carcass index 2 (weight/length of carcass) & 0.295 & 0.289 & 0.293 & 0.330 & 0.008 & 0.30 \\
\hline Conformation index $(\mathrm{g} / \mathrm{cm})$ & $1.19^{\mathrm{b}}$ & $1.02^{\mathrm{a}}$ & $1.15^{\mathrm{ab}}$ & $1.17^{\mathrm{b}}$ & 0.026 & 0.02 \\
\hline
\end{tabular}

$\mathrm{DPs}=$ Date pedicels, In each line, the numbers followed by the same exponents do not differ significantly at $\mathrm{P}<0.05$, $\mathrm{SEM}=$ Standard error of the mean

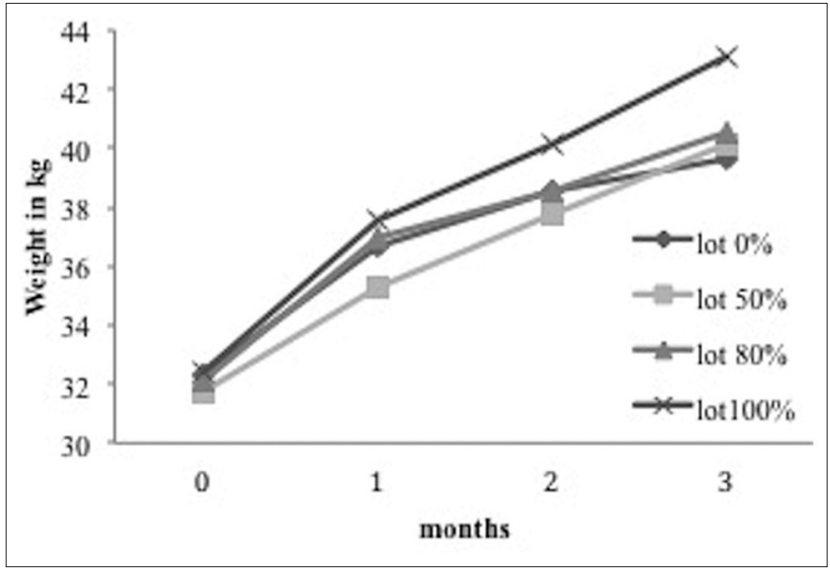

Figure-1: Change in live weight according to the substitution rates.

The thickness of the leg, width of the pelvis, shoulders and thorax, length of carcass, depth of chest, length of leg, carcass index 1 , and carcass index 2 do not differ among the groups.

The leg and muscle indices differ between the $0 \%$ and $50 \%$ groups $(\mathrm{p}<0.05)$, while the $80 \%$ and $100 \%$ groups recorded similar intermediate values (approximately 0.61 and 0.85 , respectively). The conformation index (sum of the muscle and carcass indices) is similar in the control group and the 100\% group (approximately $1.18 \mathrm{~g} / \mathrm{cm}$ ), while the $50 \%$ group records the least expressive index $(1.02 \mathrm{~g} / \mathrm{cm})$ and the $80 \%$ group displays an intermediate value $(1.15 \mathrm{~g} / \mathrm{cm})$.

The by-products of the date palm and from the abattoir used have not only improved the lamb fattening performances but have also minimized the cost of feeding with a profit margin of +DZD (Algerian Dinars) 30.93/day and/animal (Table-8).

\section{Cost price of DPs constituting the experimental basic ration}

The DPs are date harvest and packaging waste. The annual tonnage can be estimated using the quantities of dates produced at national level $(1,100,000$ tonnes in 2017) [18] and multiplying this by $1.84 \%$ [4].

The quantity of pedicels will be $1,100,000 \times 1.84 \%=20,240$ tonnes for 2017 , which are then sent as they are to landfill sites. Their recoveries will only cost transportation and labor costs. Accordingly:

- Transport costs will be DZD 5000 (truck with a capacity of 15 tonnes), given that the pedicel treatment plant is $20 \mathrm{~km}$ from the processing and/or packaging plant. The cost of transporting $1 \mathrm{~kg}$ of DPs to the treatment plant will be $0.33 \mathrm{DZD} / \mathrm{kg} /$ day.

- The labor tasked with loading, treating, and storing the pedicels is estimated at 8 workers paid $1200 \mathrm{DZD} /$ day/worker, giving $8 \times 1200 \mathrm{DZD} / 15,000 \mathrm{~kg}$ of DPs treated per day $=0.64 \mathrm{DZD} / \mathrm{kg} /$ day.

- The cost of the treatment product is estimated at $3 \mathrm{DZD} / \mathrm{kg}$, calculated as follows: $100 \mathrm{~kg}$ DPs 
treated using $5 \mathrm{~kg}$ urea, with one bag of $100 \mathrm{~kg}$ ammonitrate containing 46\% urea costing 6000 DZD.

The direct variable cost is estimated at $\mathrm{DVC}=3.97 \mathrm{DZD} / \mathrm{kg}$ DP treated

The indirect variable costs (IVC) are $5 \%$ of the DVC, i.e. $5 \times 3.97 / 100=0.1985 \mathrm{DZD} / \mathrm{kg}$

$\mathrm{IVC}=0.1985 \mathrm{DZD} / \mathrm{kg}$ DP treated

The total cost of $1 \mathrm{~kg}$ of DP treated using urea would be:

Total cost $=3.97+0.1985=4.1685 \mathrm{DZD} / \mathrm{kg}$ DP treated

The cost price of $1 \mathrm{~kg}$ of LW of the $100 \%$ group fed with CDs, treated DPs, and RCE is highly advantageous at DZD 480.07 compared to DZD $824.93 / \mathrm{kg}$ for the $0 \%$ group, representing a $42 \%$ reduction (Table-9) [1]. The profit margin rises from a negative (DZD -174.93/kg LW) to a positive value (DZD +169.52/kg LW).

\section{Discussion}

The chemical composition of CDs varies from one author to another and is linked to the proportion of pits from the processing units (date paste) and dates rejected by the packaging units [19].

Incorporating $\mathrm{CDs}$ and the RCE significantly influenced the final weights of the Ouled Djellal lambs. Alhomidy et al. [20] mentioned that the use of CDs increases both LW and digestive efficiency among sheep. Bayati et al. [21] also claimed that the use of CDs as a source of energy enhances the efficiency of the use of nitrogen in the rumen. Javidan and Khezri [9] echoed this, indicating that the use of CDs is conducive to microbial protein synthesis in sheep.

Meradi et al. [7] and Al-Shantil et al. [22], nevertheless, detected non-significant differences in final LWs with $100 \%$ substitution of corn by CDs on local lambs. In Ardi goats given feed made from date pits and date palm seeds treated with urea, Al-Suwaiegh [8] found no significant difference in final LWs.

With regard to use of CDs in ruminant rations, Kholif and El-Nor [23] and Kholif et al. [24] have illustrated the need for protein supplements which are provided by the RCE in our additional ration. According to Ziolecka et al. [25], the RCE provides a suitable environment for the growth and development of lactobacillus, preventing the growth of pathogenic microorganisms (Clostridium, Escherichia coli, Salmonella, etc.), and increases the concentration of lactic acid. Şahin et al. [14] have shown that adding RCE to the rations fed to lambs and calves has enabled to improve fattening performances.

Treating DPs with urea has also made it possible to satisfy the maintenance needs and to contribute to an increase in the final weight of lambs, in particular, the $100 \%$ group as stressed by Nyarko-Badohu et al. [2].

Using waste dates from the processing and packaging process in the rations of feeder lambs increased the total integrated quantity per day for the $100 \%$ group $(963.39 \mathrm{~g})$, without for all that affecting the $0 \%$,

Table-8: Economic cost.

\begin{tabular}{|c|c|c|c|c|c|}
\hline \multirow[t]{3}{*}{ Raw materials } & \multirow[t]{3}{*}{ Price DZD/kg } & \multicolumn{4}{|c|}{$\%$ substitution } \\
\hline & & \multicolumn{2}{|c|}{$\mathbf{0}$} & \multicolumn{2}{|c|}{100} \\
\hline & & Qt (g) & Price & Qt (g) & Price \\
\hline Control concentrate & 45 & 900.89 & 40.54 & & \\
\hline Experimental concentrate & 42.63 & & & 963.39 & 41.07 \\
\hline Control basic $\mathrm{R}$ & 20 & 500 & 10 & & \\
\hline Experimental basic $\mathrm{R}$ & 4.168 & & & 500 & 2.08 \\
\hline Price (DZD/d) ovine ration & & 50.54 & & 43.15 & \\
\hline ADG (g) & & 130.35 & & 191.07 & \\
\hline Price the consumer is willir & /e the same yield ${ }^{1}$ & $74.08^{1}$ & & & \\
\hline Profit margin (DZD/day/an & & $30.93^{2}$ & & & \\
\hline
\end{tabular}

N.B. $=$ The food prices used are the local market prices, ${ }^{1}$ Calculated by the rule of three: The farmer pays DZD 50.54 to have $130.35 \mathrm{~g}$ of grow, so for an grow of $191.07 \mathrm{~g}$, he must pay DZD 74.08, ${ }^{2} \mathrm{It}$ is the difference between the price of the farmer's ration and the experimental ration (100\%) for an grow of $191.07 \mathrm{~g}$ (DZD $43.15 \mathrm{vs} .74 .08$ ), ADG=Average daily gain

Table-9: Cost of producing $1 \mathrm{~kg}$ of live weight.

\begin{tabular}{lcc}
\hline Costs & Control group & 100\% group \\
\hline Feed costs (DZD/day) & 50.54 & Difference \\
Production costs* (DZD/day) & 107.53 .15 & -7.39 \\
ADG (g) & 130,35 & -15.72 \\
Production costs (DZD/kg) & 824,93 & 191.07 \\
Sale price of 1 kg lamb LW** & 650.00 & 480.07 \\
Profit margin (DZD/kg LW) & -174.93 & 650.00 \\
\hline
\end{tabular}

*Calculated by the rule of three; feed costs $=47 \%$ of total production cost [1], * Sale price of $1 \mathrm{~kg}$ lamb LW in the experimental farm during the period of Aïd El Kebîr, ADG=Average daily gain, LW=Live weight 
$50 \%$, and $80 \%$ groups $(900.89,917.85$, and $922.32 \mathrm{~g}$, respectively). These results are consistent with those of Meradi et al. [7] and consolidated by those of Bayati Zadeh et al. [21]. The most expressive FCR is that of the $100 \%$ group, with $5.08(\mathrm{p}<0.05)$.

The ADG is highly significant $(\mathrm{p}<0.05)$ for the $100 \%$ batch $(191.07 \mathrm{~g} / \mathrm{d})$ with $+61 \mathrm{~g} / \mathrm{d}$ compared to the control group. Chehma and Longo [26] found that incorporating $75 \%$ CDs results in an ADG of $150 \mathrm{~g}$ and concludes that the CDs have the same properties as an energy shot for sheep fattening.

The carcass yield was most expressive for the $80 \%$ and $100 \%$ groups, at $47.31 \%$ and $48.77 \%$, respectively. This improvement is also observed by Farhan et al. [27], for a diet based on date pits. The variation in the thickness of back fat was less expressive for the $100 \%$ group $(3.23 \mathrm{~cm})$ and was due to the combination of the nitrogen provided by the pedicel treatment and the rate of CDs $(60 \%)$ which synthesized microbial protein in the rumen, giving rise to a final weight of $43.10 \mathrm{~kg}$ and reducing the lipogenesis of the sugars provided by the CDs. The conformation rate was not significant between the $0 \%$ and $100 \%$ groups, echoing the observations of Sañudo et al. [28] who noted that diet has little impact on this index.

\section{Conclusion}

The use of by-products of the date palm (CDs and pedicels) combined with RCE in animal feed with a view to fattening sheep, in particular in oasis zones, represents an alternative in enhancing growth performances and carcass characteristics and offers a relatively cheap prospect for the availability of red meat for populations with low purchasing power.

\section{Authors' Contributions}

AB prepared the ground conditions and collected the data, RA revised the manuscript, EM carried out and drafted the economic analysis, YA performed the analysis of the data, FA designed the study and drafted, and HSA revised the manuscript. All authors have read and approved the final manuscript.

\section{Acknowledgments}

We would like to thank, the Joint Evaluation and Foresight Committee, the Hubert Curien partnerships (Algerian-French cooperation: Tassili project 16/ MDU/954) and the pilot farm Yahïa Ben Aïchouche (Algeria) for their funding.

\section{Competing Interests}

The authors declare that they have no competing interests.

\section{References}

1. Belhouadjeb, F.A. and Chehat, F. (2013) The cost of production and the competitiveness of the Algerian sheep meat: Case of the Lamb of Djelfa. Cah. CREAD, 29(104): 91-110.

2. Nyarko-Badohu, D.K., Kayouli, C., Ba, A.A. and Aziza, G. (1993) Valuation of cereal straws feeding sheep in northern Tunisia: 1. Treatment with alkali (ammonia/urea) 2. Complementation by molasses-urea blocks. Livest. Res. Rural Dev., 5(1): Ar8.

3. Arbouche, F. (2012) Tables de Composition et de Valeur Nutritive des Matières Premières Produites en Algérie Pour L'alimentation des Ruminants. Ed. Institut National Recherche Agronomique Algérie, Alger.

4. Chehma, A., Longo. H.F. and Siboukeur, A. (2000) Estimation of tonnage and food value of date palm by-products in sheep. Rev. Rech. Agro., no.7: 7-15.

5. Arbouche, R., Arbouche, F., Arbouche, H.S. and Arbouche, Y. (2014) Effects of the nature of nitrogen complement (apricot kernel cake vs. soybean meal) on fattening performance and carcass quality of lambs Ouled Djellal (Algeria).Rev. Méd. Vét, 165(11-12): 338-343.

6. Arbouche, F. and Arbouche, H.S. (2008) Date pedicels of southeastern Algeria: Effects of urea treatment and storage mode on their chemical composition and digestibility. Livest. Res. Rural Dev., 20(6): Ar97.

7. Meradi, S., Arbouche, F. and Arbouche, R. (2016) Valorisation of the fattening of the sheep hamra breed by the by-products of the date. Livest. Res. Rural Dev., 28: Ar4

8. Al-Suwaiegh, S.B. (2016) Effect of substituting different dietary levels of date pits and urea treated palm leaves on growth performance and nutrients digestibility of ardi goats. Res. J. Vet. Sci., 9(1): 11-18.

9. Javidan, S. and Khezri, A. (2013) Study the Effect of Using Discarded Dates on Rumen Fermentation Parameters, Nitrogen Metabolism and Performance of Kermani Sheep. The First National Congress of Dates Iranian. Shahid Bahonar University of Kerman, Iran.

10. Beranger, C. and Robelin, J. (1978) Estimation of the weight of the digestive content of cattle from the weight of the rumen content. Ann. Zootech., 27(4): 639-645.

11. Jovanovic, M. and Cuperlovic, M. (1977) Nutritive value of rumen contents for monogastric animals. Anim. Feed Sci. Tech., 2(4): 351-360.

12. Mandey, J.S., Maaruf, K., Regar, M.N., Kowelly, H.S. and Junus C. (2015) Effect of dried rumen content with and without cellulase in diet on carcass quality of broiler chickens. Int. J. Poult. Sci., 14(12): 647-650.

13. Elfaki, M.O.A., Abdelatti, K.A. and Malik, H.E.E. (2015) Effect of dietary dried rumen content on broiler performance, plasma constituents and carcass characteristics. Glob. J. An. Sci. Res., 3(1): 264-270.

14. Şahin, T., Kaya, İ., Ünal, Y., Uzlu, E. and Elmali, D.A. (2009) Effects of supplementation of the stabilized rumen extract to tuj lambs diets on fattening performance, rumen fermentations and diet digestibility. Rev. Méd. Vét., 160(1): 23-27.

15. Sauvant, D., Perez, J.M. and Tran, G. (2004) Tables INRAAFZ de Composition et de Valeur Nutritive Des Matières Premières Destinées Aux Animaux D'élevage. $2^{\text {nd }}$ éd. INRA Editions Versailles, France.

16. Laville, E., Boiux, J., Sayd, T., Eychenne, F., Marcq, F., Leroy, P.L., Elsen, J.M. and Bibe, B. (2002) The butchery conformation of lambs, study according to the genetic variability between races. INRA Prod. Anim., 15(1): 53-66.

17. Boccard, R. and Dumont, B.L (1955) Study of meat production in sheep. 1. The cutting of the carcasses. Definition of a reference section. Ann. Zootech., 4 (3): 241-257.

18. CACI. (2017) Bulletin de Statistiques Chambre Algérienne du Commerce et l'industrie. Ministère du Commerce.

19. Arbouche, F., Arbouche, R., Arbouche, Y., Arbouche, H.S. and Mennani A. (2018) Tables de composition et de valeur Nutritive des matières premières et sous produits agro-industriels de l'Afrique du Nord pour l'alimentation des ruminants. Institut National Recherche Agronomique Algérie Editeurs, Alger.

20. Alhomidy, S.N., Basmaeil, S.A.N., Al-Owaimer, A.M. and El-Wazir, M. (2011) Effect of feeding different amounts of discarded dates on growth and efficiency of digestion in 
sheep. Austr. J. Basic Appl. Sci., 5(3): 636-640.

21. Bayati, Z., Moradi, K.N. and Sajjad, A. (2015) The effects of different levels discarded dates on synthesis of microbial protein in Kermani sheep. Int. J. Life Sci., 9(5): 45-49.

22. Al-Shanti1, H.A., Kholif, A.M., Al-Shakhrit, K.J., Al-Banna, M.F. and Abu, S.I.E. (2013) Use of crushed date seeds in feeding growing assaf lambs. Egypt. J. Sheep Goat Sci., 8(1): 65-73.

23. Kholif, A.M. and El-Nor, S.A. (1998) Effect of replacing corn with powdered date seeds in diets of lactating goat in productive performance. Egypt J. Dairy Sci., 26: $25-37$

24. Kholif, A.M., El-Amary, H. and Al- Shanti, H.A. (2001) Effect of including date seeds and olive cake in diets on the yield and composition of goat and sheep milks in Southern
Saini. J. Agric. Sci., 26(8): 4764-4772.

25. Ziolecka, A., Osinska, Z. and Ziolecki, A. (1984) The effect of stabilized rumen extract on growth and development of calves. 1. Live weight gain and efficiency of feed utilization. Z. Tierphysiol. Tierer., 5(11-2): 13-20.

26. Chehma, A. and Longo, H.F. (2004) Nitrogen balance and weight gain in dromedaries and sheep, fed with by-products of date palm, barley straw and drinn Aristida pungens. Cah. Agric., 13(2): 221-226.

27. Farhan, S.M., Shakir, M.A. and El-Khalisi, I. (1969) The use of date stones for feeding and fattening Awassi lambs. Iraq. J. Agric. Sci., 4(1): 86-94.

28. Sañudo, C., Sánchez, A. and Alfonso, M. (1998) Small ruminants' production systems and factors affecting lamb meat quality. Meat Sci., 49(1): S29-S64.

$* * * * * * * *$ 